\title{
Air protection policy in the 2019 parliamentary campaign in Poland. An analysis of positions
}

\begin{abstract}
This article seeks to investigate whether the election committees that won seats in the 2019 parliamentary elections had noted the public concerns about the issue of air not meeting the normative standards, and whether they offered Poles a specific vision of an air protection policy in their election manifestoes. This analysis concerns the proposals of election committees to limit low-stack emissions. Answering the research questions posed: (1) to what extent do election manifestoes address the issue of air pollution in Poland?; (2) are the tools for the implementation of environmental policy as concerns the reduction of low-stack emissions indicated, and can they be effective? leads to the conclusion that the successful election committees noted public concerns about air pollution, and addressed air protection policy to a varied extent, though not always presenting specific solutions to eliminate low-stack emissions To achieve the purpose of the research the methods of source and comparative analysis were used.
\end{abstract}

Key words: environmental policy; environmental security; air protection policies; election manifestoes; political parties

\section{Introduction}

n the parliamentary elections held on 13 October 2019 in Poland, the political party

Prawo i Sprawiedliwość (Law and Justice, PiS) garnered the largest support $(43.59 \%$ of the votes and 235 seats in the parliament). Koalicja Obywatelska (Civic Coalition, KO), which embraced Platforma Obywatelska (Civic Platform, PO), Nowoczesna (Modern), Inicjatywa Polska (Polish Initiative) and Zieloni (The Greens), garnered $27.4 \%$ of the votes and 134 seats. Sojusz Lewicy Demokratycznej (Democratic Left Alliance, SLD) came third with $12.5 \%$ of the votes and 49 seats. The lower chamber of Polish parliament was also composed of the representatives of Koalicja Polska (Polish Coalition), made up from members of Polskie Stronnictwo Ludowe (Polish People's Party), Paweł Kukiz's association and Unia Europejskich Demokratów (Union of Polish Democrats) with support at the level of $8.55 \%$ of the votes (30 seats) and Konfederacja Wolność i Niepodległość (Confederation Liberty and Independence) with $6.81 \%$ of the votes and 11 seats. One seat was won by Mniejszość Niemiecka (German Minority) (Państwowa Komisja Wyborcza, 2019). In this way, the parliament elected in 2019 featured a representation of political parties from diverse ideological backgrounds.

Air pollution is one of the ecological threats that attracts the attention of the media and public opinion in Poland. From August 2018 to July 2019, most publications on the environment $(385,000)$ addressed the issue of "smog," "drought" came second, featuring in 122,000 publications and "recycling" was third with 113,000 (Jędrze- 
jewska, Jodłowski, Knap et al., 2019, pp. 34-35). The increasing media coverage of environmental threats translates into greater ecological awareness of Poles. In 2010, only $7 \%$ of them indicated the state of the environment (including air pollution and smog), when asked about the most important problems in their town or municipality, compared to $24 \%$ in 2018 . In the 2018 edition of the survey, only the situation in the healthcare system (50\%) and the condition of roads (40\%) were considered more important. Environmental issues turned out to be particularly important for the inhabitants of large cities (indicated by $36 \%$ of respondents in cities of over 100,000 inhabitants, and 52\% in cities of over 500,000 inhabitants) (Cybulska, 2018, pp. 9-10 and 12).

Research commissioned by the Ministry of the Environment shows a growing public interest in the issue of air quality. The most important nationwide problems of the natural environment identified by respondents in 2012 included garbage (49\%), air pollution, water pollution and natural disasters (34\% of responses each); in 2018 the numbers were as follows: air pollution $-62 \%$, garbage $-47 \%$, climate change $-39 \%$ (Szatanowska, Kotlewska, Licznerska et al., 2018, p. 24). Respondents in this survey were shown a list of areas addressed by the state and requested to indicate the three where the most needs to be done in Poland. Environmental protection was indicated by 7\% in 2012, and by as many as $18 \%$ of respondents in 2018 . Interestingly, in the 2018 edition of the survey, environmental protection was indicated more than education and parenting (16\%), internal affairs and security - activities of the police, special services, fire brigades and border guards (13\%), national defence (11\%), higher education and science $(8 \%)$, physical culture and sport (5\%), and national culture and heritage (4\%) (ibid., p. 19). Importantly, Poles realise the seriousness of health problems related to low-quality air. In a 2019 study commissioned by the European Commission on the attitudes of Europeans towards air quality, $93 \%$ and $92 \%$ of Poles indicated that diseases of the cardiovascular and respiratory systems, respectively, are a "serious problem" in their country (Special, 2019, pp. 12 and 14).

Air protection policy is implemented as part of environmental protection policy, also known as ecological policy, which is defined as the conscious and purposeful activity of the state managing the environment; that is using environmental resources and benefits, protection and shaping of ecosystems and selected elements of the biosphere (Górka, Poskrobko, Radecki, 2001, p. 64). In broader terms, environmental policy is implemented, alongside public administration bodies, by political parties, social organisations and opinion-forming entities, such as the media, academic researchers, pressure groups and citizens. All these have or pursue power, and participate in or influence the political decision-making process in this regard (Macek, 2014, p. 468). There can be both reactive and preventive environmental policies. The former consist of the implementation of projects aimed at eliminating or minimising the emissions of pollutants and waste generated in production and consumption processes, as well as reducing the environmental nuisance of previously generated pollutants and waste. This is referred to as the "end-of-pipe approach" because special attention is given to pollutants already introduced into the environment as a result of fossil fuel burning, among others. The latter type of environmental policy is defined as preventive or integrated. It consists of stimulating the transition from "dirty" to 
clean technologies with a sufficiently low level of pollutant emissions per production or consumption unit (Czaja, Fiedor, Graczyk, Jakubczyk, 2002, pp. 256-257). Environmental policy includes the following specific policies: nature protection policy, water management policy, spatial management policy, land surface policy, and climate and atmosphere protection policy. The latter emerged at the beginning of the 21 st century, and includes air purity, among others. Environmental policy deals with the environment and its appropriate quality from the point of view of the biological (low-quality elements of the environment endanger health and life), social (e.g. recreation, education) and economic needs of people. Many environmental resources, such as the atmosphere, are public goods that are universally available and cost-free, often leading to over-exploitation and degradation. For this reason, state intervention is necessary to force users of the environment to use them rationally (Poskrobko, Poskrobko, 2012, p. 92 and 97).

This article seeks to investigate whether the political parties that won seats in the 2019 parliamentary elections had noted the public concerns about the issue of air not meeting the normative standards, and whether they offered Poles a specific vision of an air protection policy in their election manifestoes. The election manifesto of a given political group constitutes a formal acknowledgement of its objective situation, the directions of action and possibilities of transforming social, economic and political structures (Chmaj, Żmigrodzki, 1998, p. 99). This analysis concerns the proposals of election committees to limit low-stack emissions, or the emissions of air pollutants from chimneys (emitters) less than 40m in height (Poradnik antysmogowy, 2018, p. 1). The issue of exceeding normative values of pollutant concentrations in Poland applies mainly to suspended dust (including $\mathrm{PM}_{10}$ - up to $10 \mu \mathrm{m}$ in diameter and very fine dust $-\mathrm{PM}_{2.5}$ - with particles below $2.5 \mu \mathrm{m}$ ) as well as of the benzo(a)pyrene in the dust. The allowed concentration level of the latter was exceeded at most measurement stations in Poland in 2019 (in ca. 78\% of measurement zones). The state air quality monitoring services recorded exceeded concentrations of $\mathrm{PM}_{10}$ suspended dust in ca. $48 \%$ of measurement zones (as concerns the daily standard) and of $\mathrm{PM}_{2.5}$ in $17 \%$ of the zones (Główny Inspektorat Ochrony Środowiska, 2020, pp. 54, 111, 98). These high levels are mainly related to the burning of fuel in individual households and local low thermal power boiler houses in public utility buildings or commercial facilities, among others, which are referred to as low-stack emission sources. In 2019, this type of source accounted for $41 \%$ of $\mathrm{PM}_{10}$ dust emitted into the air (only $3 \%$ was generated by fuel burning in energy industries ${ }^{1}$ ), $49 \%$ of $\mathrm{PM}_{2.5}$ (again, only $3 \%$ was generated by fuel burning in energy industries) and over $90 \%$ of benzo(a)pyrene (with households accounting for 89\%) (Ministry of Climate and Environment, 2021a, pp. 29, 31, 40-41). This study aims to answer the following questions: firstly, to what extent do election manifestoes address the issue of air pollution in Poland; and, secondly, are the tools for the implementation of environmental policy as concerns the reduction of low-stack emissions indicated, and can they be effective?

${ }^{1}$ Key sources of air pollution in the "energy industries" sector are public power plants, district heating plants, industrial plants as well as petroleum refining (Ministry of Climate and Environment, 2021, p. 47). 


\section{Law and Justice - the Clean Air Programme continued}

The party with the largest support, Law and Justice, indicated seven pillars in its election manifesto: (1) the state; (2) social policy and health protection; (3) development; (4) education and sports; (5) rural areas and agriculture; (6) environmental protection; and (7) foreign and defence policy. Ten pages were devoted to environmental protection policy the introduction to which read that "Law and Justice treats environmental protection as a pillar of a modern welfare state and a condition for sustainable development" (Prawo i Sprawiedliwość, 2019, p. 161). The following problem areas were identified: the prevention and mitigation of climate change, combating smog, waste management and nature protection. The discussion of individual issues followed a presentation of what PiS had already achieved in terms of the environmental protection policy pursued after the 2015 parliamentary elections, in which PiS candidates won the majority of seats in the Sejm (235) and the Senate (61) (Państwowa Komisja Wyborcza, 2015a and 2015b).

The first page of the section dedicated to environmental policy indicated the priority programme implemented by the National Fund for Environmental Protection and Water Management (NFOŚiGW) in 2016-2022 "Improving air quality - reducing energy consumption in construction" as an achievement of environmental measures. The goal of the programme was to reduce or prevent carbon dioxide $\left(\mathrm{CO}_{2}\right)$ emissions by at least $47,600 \mathrm{Mg}$ /year through increasing generation of energy from renewable sources and reducing energy consumption in buildings. The programme's budget amounted to up to PLN 1,129,567,000, earmarked for subsidies (up to PLN 371,875,000) and loans (up to PLN 757,710,000) granted for the purposes of modernisation, including, among others, the thermal modernisation of museums, hospitals and the like, historic and religious buildings with accompanying structures, student dormitories and other buildings intended for culture, religious worship, education, care and learning. It also provides for the reconstruction of heating systems (including the replacement of heat sources, including their replacement with renewable ones) and the implementation of energy management systems in buildings (Program priorytetowy „Poprawa jakości powietrza”, pp. 1-2 and 5). The election spot broadcast on 12 September 2019 (Polskie Radio 24, 2019) stated that, "following their formal evaluation, almost 850 applications for funding to the total amount of PLN 1.4 billion are currently being processed" (Prawo i Sprawiedliwość, 2019 , p. 161). This meant that interest from potential beneficiaries exceeded the programme budget one year before the deadline for submitting applications on 31 December 2020 .

Interestingly, the name of the programme could have been misleading for voters. The main concern of air protection in Poland is not $\mathrm{CO}_{2}$ emissions, but what is called "winter smog." which consists mainly of very high concentrations of fine dust (PM) and sulphur dioxide $\left(\mathrm{SO}_{2}\right)$. To a lesser extent it also contains other pollutants, such as carbon monoxide $(\mathrm{CO})$, nitrogen dioxide $\left(\mathrm{NO}_{2}\right)$ and organic compounds. The term "smog" defines episodes of sudden and severe air pollution, caused in the wintertime by increased and ineffective burning of fossil fuels, especially in households (stoves and boilers), in unfavourable weather conditions, such as no wind or fog, leading to an increase in pollutant concentrations in the atmosphere at ground level. Smog may be aggravated by the local 
topography, for instance if the emissions sources are located in a valley (Juda-Rezler, 2006, pp. 107-108). Greenhouse gases are compounds other than air pollutants. The main greenhouse gas $-\mathrm{CO}_{2}$, becomes a health hazard when its concentration reaches the level of ca. $0.5 \%$, which is never the case outdoors. The only gas that belongs to both groups is ozone $\left(\mathrm{O}_{3}\right)$, a component of photochemical smog generated by car exhaust fumes (for more see: Kleczkowski, 2020, pp. 65 and 180). Therefore, it is difficult to understand why the reduction of $\mathrm{CO}_{2}$ emissions, rather than dust emissions was chosen as an indicator of success for a programme to improve air quality. The measures proposed in the programme "Improving air quality - reducing energy consumption in construction" (due to thermal modernisation) will result in reduced energy consumption, which will translate into a reduction in $\mathrm{CO}_{2}$ emissions, but the question remains to what extent they will contribute to reducing smog (which would be the case if, for instance, a small coal-fired boiler room heating a culture centre was replaced).

The Clean Air Programme, which stands a real chance of affecting air quality, was presented halfway through the section of the election manifesto dedicated to environmental protection, discussing the achievements under the heading "Combating Smog." The programme consists of subsidising the replacement of an old source of heating with one generating fewer or zero emissions, and subsidising home insulation by the owner or co-owner (a natural person) of a single-family residential building, or of a separate apartment in a building with its own land and mortgage register. In the version of the programme valid in the election year, subsidies were also available for the owners of new buildings. ${ }^{2}$ The level, and form of subsidies (non-returnable subsidy and/or loan) depended on the beneficiary's income (Program priorytetowy „Czyste Powietrze”, 2019, p. 1 and 3). ${ }^{3}$ Thermal modernisation of residential buildings combined with the replacement of high emission heat sources is the basic measure for improving air quality in Poland, considering that about $70 \%$ of single-family houses, estimated to number ca. 5.4 million, are uninsulated or low insulation standard buildings (Pytliński, 2014, p. 9) and that the low-stack emissions they generate are the main source of smog (Mazurek, 2018, p. 13). Solid fuels serve to heat 4.5 million buildings (over $80 \%$ of all domiciles). In 1.7 million of these, coal-fired boilers of 10 years or older are found, the majority boiler hoppers with low efficiency (Pytliński, 2018, pp. 34-35). The budget of the programme to be implemented from 2018 to 2029 amounts to over PLN 103 billion and provides for the replacement of 3 million ineffective heat sources and carrying out thermal modernisation in slightly more than 3 million buildings or domiciles among other things (Program priorytetowy „Czyste Powietrze”, 2019, p. 1). Importantly, the programme allows heating sources to be replaced with fifth-class coal-fired furnaces (whenever the connection to a heating network or gas distribution network in a given area is not possible or not

${ }^{2}$ People who were building a house could apply for subsidies to purchase and install a new heat source, heat, gas or electricity connection, and mechanical ventilation with heat recovery, provided that the investment was completed by December 31, 2019. They could also apply for support for the purchase of solar collectors, photovoltaic installation or mechanical ventilation with heat recovery until the next version of the programme from May 2020 was announced, which did not include owners of residential buildings under construction among the beneficiaries.

3 The Clean Air Programme has undergone several updates. Its current version (as on 25 August 2021) has been in force since 1 July 2021 (Od dzisiaj, 2021) and can be found here: https://portal.wfosigw.pl/dokumenty/Dokumenty_od_01-07-2021/1.pdf (25.08.2021). 
economically justified), thereby failing to promote the departure from the energy source generating the highest emissions. ${ }^{4}$

The Clean Air Programme was given little attention, although it offers subsidies that could be used by numerous voters to make a real impact on air condition in their place of residence. The election manifesto said that, "More than 72,500 applications have already been submitted for a total amount of nearly PLN 1.7 billion and nearly 28,000 contracts worth nearly PLN 500 million have been signed. It is estimated that 100,000 applications will be submitted by the end of 2019" (Prawo i Sprawiedliwość, 2019, p. 165). These thousands of applications and millions of zlotys could give the impression that the Clean Air Programme was operating efficiently. It should be mentioned, however, that the pace of its implementation, especially in the first ten months of its operation, when only regional environmental protection and water management funds were comprehensively dealing with applicants, was very slow, and was criticised, among others, by air protection organisations, such as Polish Smog Alert (see i.e. Fikcyjny, 2019). From 19 September 2018, when the applications began to be submitted, until the end of December that year, 25,519 applications were submitted for subsidies to the amount of PLN 405 million, and for loans to the amount of nearly PLN 144 million. Only 59 contracts with applicants were signed for the total subsidy requested, amounting to PLN 636,000. The implementation of projects in the programme can last until 30 June 2029 (Narodowy Fundusz Ochrony Środowiska i Gospodarki Wodnej, 2019, p. 27), which means that an average of ca. 281,000 houses should be thermally modernised and replace solid fuel boilers every year. From 21 January 2019 (when the programme was resumed after the thermal modernisation relief was launched) to 28 June 2019, nearly 38,500 applications were submitted and almost 26,000 contracts were signed (Minister, 2019). The authors of the election manifesto did not indicate when the 28,000 contracts in question had been signed, but it can be assumed that the number comes from the end of August/the beginning of September 2019, which would mean that $10 \%$ of the average annual goal had been achieved during the first 12 months of the Clean Air Programme. Importantly, signing a contract does not equate to the implementation of the project (which cannot exceed the deadline of 30 months from the date of submitting the application for co-financing in the form of a subsidy or, in the current version of the programme, 18 months from the date of submitting the application for partial loan repayment). It can therefore be assumed that the Clean Air Programme was not emphasised in the election manifesto because of its inefficient implementation.

PiS also referred to such initiatives for clean air as the regulation on requirements for solid fuel boilers (Rozporzadzenie Ministra Rozwoju, 2017) and the regulation on quality requirements for solid fuels (Rozporzadzenie Ministra Energii, 2018). According to the authors of the electoral manifesto, the former led to a change in the boiler market, making it impossible to purchase older, outdated models. This statement is highly debatable, as unclassified boilers were not completely eliminated. Therefore, an amendment to the regulation was adopted 18 months later (Rozporzadzenie Ministra Przedsiębiorczości, 2019). However, the amendment did not introduce the key solution, namely the obligation to replace old furnaces that did not meet regulatory requirements. In Poland,

${ }^{4}$ Subsidies for coal boilers will only be abandoned starting on 1 January 2022 (https://czystepowietrze.gov.pl/od-dzisiaj-obowiazuja-zmiany-w-programie-czyste-powietrze/, 27.07.2021). 
approximately 1,700,000 single-family houses are equipped with ten-year-old, or older coal-fired boilers, most of them low-efficiency charging boilers (Pytliński, 2018, p. 71). These primitive heating devices that emit significant amounts of pollutants will gradually be eliminated due to legal regulations. Nevertheless, it should be taken into account that a solid fuel boiler is typically used for up to 20 years, so a sudden improvement in air quality as a result of the regulation on requirements for solid fuel boilers should not be expected (for a more extensive analysis see: Sakson-Boulet, 2020, pp. 101-102). In the opinion of the authors of PiS's election manifesto, the second regulation, namely that on the quality standards for solid fuels intended for use in households and installations with a thermal power below $1 \mathrm{MW}$, had resulted in the elimination of "around $14 \%$ of the mass of solid fuels, mainly [...] coal slurry and flotation concentrates." Even though the sale of these fuels was theoretically banned, they could still be purchased; and the emissions standards established were considered insufficient by environmental and social organisations, were critically assessed at the consultation stage by the representatives of local authorities and during an audit of air protection policy conducted by the Supreme Audit Office (for more see: ibid., pp. 103-105).

PiS did not consider launching new programmes and solutions as a measure leading to cleaner air, but declared the continuation of the Clean Air Programme, which was supposed to halve the emissions of pollutants from the municipal and housing sector. The pace of programme implementation continues to call into question the achievement of all its objectives. Between 19 September 2018 (the first day of submitting applications to the Clean Air Programme) and 30 July 2021, only 227,087 contracts were signed (the programme website does not provide information on how many investments have been implemented and settled since the beginning of the programme) whereas, as already mentioned, an average of around 281,000 houses were to undergo thermal modernisation and replacement of boilers per year (Czyste Powietrze w liczbach).

\section{The Civic Coalition - to eliminate carbon from home heating by 2030}

In its election manifesto, the Civic Coalition indicated six key tasks of the state in the following areas: (1) freedom and democracy; (2) health care; (3) wages and economy; (4) environment; (5) education and culture; and (6) care for senior citizens. The main challenges for environmental policy were presented on fourteen pages. Although the election manifesto section dedicated to environmental protection is titled "Climate and Water," the first issue it addresses is combating smog (Koalicja Obywatelska, 2019, pp. 91-92). The Civic Coalition declared its commitment to eliminating coal from heating homes and apartments by 2030 and replacing unclassified boilers and furnaces with heat pumps and district heating. However, no support mechanisms were set out for those property owners who would have to replace their heat sources. 2035 was adopted as the deadline to abandon coal combustion in heating networks, but in the case of small heating networks in district cities the deadline is shorter -2030 . Coal would be replaced in energy production by photovoltaic installations and wind farms (Koalicja Obywatelska, 2019, p. 92).

It was emphasised in the election manifesto that " $80 \%$ of heating systems in Poland" were ineffective, high emission systems (ibid.). However, the high emissions con- 
cern carbon dioxide $\left(\mathrm{CO}_{2}\right)$. Due to their burning mainly coal, ${ }^{5}$ energy industries emitted $46.9 \%$ of this greenhouse gas in Poland in 2019 (Ministry of Climate and Environment, 2021 b, p. 16), ca. $22 \%$ of which came from the domestic heating sector (Rubczyński, 2019 , p. 7). District heating is generated in combined heat-and-power plants or heating plants, from where a network of pipelines distributes it to buildings. In installations with devices filtering air pollution, fuel is burnt at an optimal temperature and does not emit significant amounts of air pollutants, which is confirmed by the above-quoted data from the National Unit for Emission Inventory and Reporting (Ministry of Climate and Environment, 2021a). It is clear that the transition in the generation of district heating from burning coal to, for example, solar or wind energy conversion will benefit air quality (further reduction of dust, nitrogen oxides and sulphur emissions), but above all it will reduce $\mathrm{CO}_{2}$ emissions. The website of the Chamber of Commerce Polish District Heating states that the data collected in the course of the certification process, conducted by the Institute for Certification and Emission of Buildings in 2018, confirmed that dust emissions were reduced by $98 \%$, benzo(a)pyrene by $99.42 \%$, and carbon monoxide by $99.4 \%$ compared to the emissions of an individual coal-fired boiler generating the same amount of heat (Izba Gospodarcza Ciepłownictwo Polskie, Ogranicz smog w mieście). As part of measures to reduce low-stack emissions, existing high emission heat sources are being replaced by individual sources (such as gas furnaces) where a connection to the heating network is not possible or economically justified. In the context of air quality, however, it should be noted that $80 \%$ of heating systems mentioned in the election manifesto did not meet the requirements of the Directive on Energy Efficiency (Directive, 2018), thereby making it impossible to obtain financing for their modernisation from EU sources; additionally, due to the high costs of $\mathrm{CO}_{2}$ emissions allowances, this will result in increasing heat prices, customers looking for cheaper heating sources being disconnected, a worse economic situation for heating companies and, ultimately, heating plants closing down (for more see Rubczyński, 2019, pp. 14-16).

The Civic Coalition assumed in its election manifesto that the elimination of non-ecological heating sources would be accompanied by a continuing thermal modernisation programme, for which EUR 25 billion would be earmarked (Koalicja Obywatelska, 2019, p. 100).

\section{Democratic Left Alliance - the end of coal dominating individual heating and district heating by 2035}

The election promises announced in the election manifesto titled "A Poland of Tomorrow. The Main Postulates of the Left" were grouped with reference to three values, namely cooperation, community and freedom. The first substantive page of the election manifesto dedicated to cooperation, featured a section "Climate," where co-financing was promised for the replacement of "two million domestic coal-fired stoves with modern, emission-free heating installations within 15 years" (heat pumps) and the development of heating networks (Komitet Wyborczy Sojusz Lewicy Demokratycznej, p. 3).

${ }^{5}$ Coal accounted for $74 \%$ of fuel burnt in district heating in 2018 (Urząd Regulacji Energetyki, 2019, p. 13). 
Most of the energy was to come from renewable sources such as solar panels, wind farms and heat pumps by 2035 (ibid.). The manifesto took into account investments in the thermal modernisation of buildings, but no plan was presented in this regard.

\section{Polish People's Party. Polish Coalition - the replacement of high emission heat sources including a subsidy covering the entire replacement cost for the poorest households}

The Polish Coalition presented its election postulates in the "We Unite Poles" manifesto in the following areas: (1) the civic republic; (2) family and social policy; (3) available health care; (4) education; (5) agriculture and rural areas; (6) challenges related to climate change, clean air, cheap electricity; (7) investments as the key to development; (8) development of small and medium-sized enterprises; (9) responsible foreign policy; and (10) local government and civil society. Although the introduction to the section discussing environmental policy focused on the problem of climate change, the last sentence read that "Caring for the environment and fighting for clean air is becoming [...] one of the most important, if not the most important challenge for successive governments" (Polskie Stronnictwo Ludowe. Koalicja Polska, 2019, p. 17).

The manifesto featured a section "Combating Smog," where a ban on the installation of stoves and boilers that do not meet environmental protection standards was proposed. However, it did not specify which standards this concerned. In the election year, the amended regulation on the requirements for solid fuel boilers (which was referred to by PiS in its election manifesto) was already in force. Pursuant to these regulations, boilers with a capacity of up to $500 \mathrm{~kW}$, i.e. those used in households, available on the market had to comply with the 5th class of parameters, the highest in terms of energy and emissions efficiency, in accordance with the European standard EN 303-5 of 2012, which specified the maximum emissions limits for specific pollutants (dust, carbon monoxide and organic gaseous pollutants) and regulated the minimum required thermal efficiency of boilers (Rozporzadzenie Ministra Rozwoju, 2017). As of 1 January 2020, stricter standards introduced by the European Commission regulation on energy efficiency and emissions standards came into force; for instance, nitrogen oxide emissions standards were set and the requirement that the manufacturers specify average seasonal boiler efficiency (Commission Regulation, 2015). It was therefore unclear which other standards the boilers on the market should comply with, according to the Polish Coalition.

The authors of the manifesto proposed that the purchase of stoves be subsidised up to $75 \%$, or $100 \%$ of their price, provided that the income criterion was met (Polskie Stronnictwo Ludowe. Koalicja Polska, 2019, p. 17). It appears that this concerned boilers rather than stoves. Stoves heat only the rooms in which they are located. This applies both to tiled stoves, which are still found in urban tenement houses or in the countryside, as well as to modern stoves with some type of regulation such as free-standing wood stoves, which arouse interest mainly due to their aesthetic values or the potential for reducing heating costs. A central heating boiler is used to heat all the rooms in a house or apartment (and provide hot utility water), distributing heat evenly throughout the building. More importantly, however, the manifesto allowed the heating source to be replaced 
with a coal-fired stove or boiler, even though it stated that "we will consistently be abandoning coal" (ibid.).

\section{Confederation Liberty and Independence - continued coal burning while developing cleaner technologies}

The manifesto "Poland for You" featured election promises grouped around "the "Confederation's five," namely: (1) universal tax relief; (2) quick and efficient courts of justice; (3) educational and cultural voucher; (4) national security; and (5) healthy life. The latter item, as presented on page 17, was about protecting lives, clean air and water, protecting forests and healthy food. The authors stated the following: "Our compatriots deserve a healthy life - clean water, better air in cities, an efficient health care system and healthy food" (Konfederacja Wolność i Niepodległość, 2019, p. 18). The voters could then read a message printed in red and larger font size: "We know how to do this! Clean air in Polish cities." Unfortunately, the Confederation did not reveal what their effective air protection policy would consist of. With regard to the issue of low-stack emissions, the Confederation said that it did not oppose generating energy from coal, but supported the use of newer, more efficient and cleaner technologies in the energy sector (ibid.).

\section{The German Minority - a transition from coal towards renewable sources}

In the "Opolskie Matters" manifesto, election postulates were grouped around four issues such as: (1) identity and culture; (2) family; (3) civil society; and (4) economy and infrastructure. The last issue, discussed in the section titled "Family Matters!", is "Ecology." The "transition to renewable energy sources" was recognised as key to combating smog, and support for a gradual shift from coal was declared (Komitet Wyborczy Wyborców Mniejszość Niemiecka, 2019). However, no specific date was given to stop burning coal, both for electricity and heat generation. The manifesto addressed the issue of facilitating easier access to environmentally friendly stoves and heating systems by supporting programmes to reduce $\mathrm{CO}_{2}$ emissions. As in the Polish Coalition's manifesto, it can be assumed that the authors meant boilers.

\section{Conclusion}

The above analysis confirms that, in the 2019 parliamentary elections, the successful election committees noted public concerns about air pollution, and addressed air protection policy to a varied extent, though not always presenting specific solutions to eliminate low-stack emissions. The conclusions are confirmed by the answers to the research questions posed in the introduction.

(1) To what extent do election manifestoes address the issue of air pollution in Poland? 
For the first time, the issue of poor air quality was addressed in the election manifestoes of all election committees that won seats. In the previous election in 2015, PiS, among others, did not consider this problem as important for voters (Prawo i Sprawiedliwość, 2014, environmental protection is discussed on pp. 104-106). This changed during the next election campaign. In 2019, the subject of reducing low-stack emissions was discussed in the most detail in the election manifestoes of PiS and the Civic Coalition. The Confederation Liberty and Independence took a different approach, mentioning only slogans. The remaining election manifestoes, including that of the German Minority, discussed the issue in greater length. The Democratic Left Alliance addressed the issue concerned on the first page, which means that it appreciated the fact that the consequences of air pollution, including, among other things, 250,000-300,000 Poles suffering from various diseases annually (Adamkiewicz, Bochniarz et al., 2018, p. 148) and premature death of almost 50,000 people per year in Poland as a result of excessive exposure to $\mathrm{PM}_{2.5}$ dust, nitrogen dioxide and ground-level ozone, are priority challenges. The remaining election committees referred to the problem of smog later on in their respective manifestoes: the Polish Coalition discussed it in the middle, and the Confederation Liberty and Independence only on the penultimate page. PiS considered environmental policy to be more important than foreign and defence policy, and the Civic Coalition - more important than education, culture and senior policy.

(2) Are the tools for the implementation of environmental policy as concerns the reduction of low emissions indicated, and can they be effective?

Table 1 below summarises the proposals for reducing low-stack emissions presented in the election manifestoes analysed, taking into account whether the election committees identified the key measures to reduce smog in Poland, namely thermal modernisation of residential buildings combined with the replacement of high emission heat sources.

Table 1

The election manifestoes of selected election committees in the 2019 parliamentary elections as concerns the issue of reducing low-stack emissions

\begin{tabular}{|c|c|c|c|}
\hline \multirow[b]{2}{*}{$\begin{array}{l}\text { Election } \\
\text { committee }\end{array}$} & \multicolumn{3}{|c|}{ Election manifesto } \\
\hline & $\begin{array}{c}\text { Thermal modernisation } \\
\text { of residential single-family } \\
\text { buildings }\end{array}$ & $\begin{array}{l}\text { Replacement of high } \\
\text { emission heating sources }\end{array}$ & $\begin{array}{l}\text { Ban on coal burning } \\
\text { to heat houses in } \\
\text { a specific time frame }\end{array}$ \\
\hline 1 & 2 & 3 & 4 \\
\hline $\begin{array}{l}\text { Law and } \\
\text { Justice (PiS) }\end{array}$ & $\begin{array}{c}\text { yes, } \\
3 \text { million buildings over } 11 \\
\text { years } \\
\text { support for investments under } \\
\text { the Clean Air Programme }\end{array}$ & $\begin{array}{c}\text { yes, } \\
\text { replacement of } 3 \text { million } \\
\text { installations over 11 years, } \\
\text { under specific conditions } \\
\text { including solid fuel burning } \\
\text { sources of heat } \\
\text { support for investments under } \\
\text { the Clean Air Programme }\end{array}$ & no \\
\hline $\begin{array}{l}\text { Civic Coalition } \\
\text { (KO) }\end{array}$ & $\begin{array}{c}\text { yes, } \\
\text { no information on support for } \\
\text { investments from the state } \\
\text { budget }\end{array}$ & $\begin{array}{c}\text { yes, } \\
\text { investment support at the } \\
\text { level of EUR 25 billion }\end{array}$ & $\begin{array}{c}\text { yes, } \\
\text { starting in } 2030\end{array}$ \\
\hline
\end{tabular}




\begin{tabular}{|l|c|c|c|}
\hline \multicolumn{1}{|c|}{1} & 2 & 3 & 4 \\
\hline $\begin{array}{l}\text { Democratic Left } \\
\text { Alliance (LSD) }\end{array}$ & $\begin{array}{c}\text { yes, } \\
\text { declared investments in ther- } \\
\text { mal modernisation, no details } \\
\text { provided }\end{array}$ & $\begin{array}{c}\text { yes, } \\
2 \text { million installations over } \\
15 \text { years }\end{array}$ & no \\
\hline $\begin{array}{l}\text { Polish Coalition } \\
\text { (KP) }\end{array}$ & no & $\begin{array}{c}\text { yes, } \\
\text { including coal stoves }\end{array}$ & no \\
\hline $\begin{array}{l}\text { Confederation } \\
\text { Liberty and Inde- } \\
\text { pendence }\end{array}$ & no & no & no \\
\hline German Minority & & no & no \\
\hline
\end{tabular}

Source: Own analysis.

Three election committees (Law and Justice, Civic Coalition and Democratic Left Alliance) rightly assumed that reducing smog requires thermal modernisation combined with the replacement of ineffective and high emission heat sources. As indicated in the analysis, nearly 3.8 million residential buildings in Poland are not insulated or have low insulation standards, and low-stack emissions from these houses are the main source of smog. The Civic Coalition failed to specify how many buildings would be covered in both areas. The Democratic Left Alliance, on the other hand, set a goal of replacing 2 million heating sources within the timeframe of 15 years. The Clean Air Programme provided for the replacement of 3 million high emission boilers and thermal modernisation over a period of 11 years. The Polish Coalition limited its activities planned in this area only to the replacement of heat sources, while the Confederation and the German Minority did not provide solutions in any of the areas concerned. Therefore, a significant reduction of low-stack emissions could be achieved by the Clean Air Programme of PiS, provided that the pace of its implementation improves considerably. Another weakness of PiS's policy was that there was no plan to completely abandon coal burning in households and in the heating sector. None of the election committees proposed the obligation to replace old boilers that did not meet the standards of the regulation on the requirements for solid fuel boilers.

\section{Bibliography}

Adamkiewicz Ł., Bochniarz Z., Mucha D., Gayer A., Badyda A. (2018), Konsekwencje spoteczne i ekonomiczne zanieczyszczenia powietrza, in: Smog. Konsekwencje zdrowotne zanieczyszczeń powietrza, PZWL Wydawnictwo Lekarskie, Warszawa.

Chmaj M., Żmigrodzki M. (1998), Wprowadzenie do teorii polityki, Wydawnictwo Uniwersytetu Marii Curie-Skłodowskiej, Lublin.

Commission Regulation (UE) 2015/1189 of 28 April 2015 implementing Directive 2009/125/EC of the European Parliament and of the Council with regard to ecodesign requirements for solid fuel boilers, OJ EU L 193/100.

Cybulska A. (2018), Co zmienito się w naszej miejscowości?, a report on the research by the Public Opinion Research Centre (CBOS), no. 92/2018.

Czaja S., Fiedor B., Graczyk A., Jakubczyk Z. (2002), Podstawy ekonomii środowiska i zasobów naturalnych, Wydawnictwo C.H. Beck, Warszawa.

Czyste Powietrze w liczbach, https://czystepowietrze.gov.pl, 2.08.2021. 
Directive (EU) 2018/2002 of the European Parliament and of the Council of 11 December 2018 amending Directive 2012/27/EU on energy efficiency, OJ EU L 328/210.

Fikcyjny Program Czyste Powietrze - PAS zapytat o realizację rzadowego planu (2019), Polski Alarm Smogowy, https://polskialarmsmogowy.pl/2019/02/fikcyjny-program-czyste-powietrze-paszapytal-o-realizacje-rzadowego-planu/, 28.07.2021.

Główny Inspektorat Ochrony Środowiska (2020), Ocena jakości powietrza w strefach $w$ Polsce za rok 2019. Zbiorczy raport krajowy z rocznej oceny jakości powietrza w strefach wykonanej przez GIOŚ wedtug zasad określonych w art. 89 ustawy - Prawo ochrony środowiska, Warszawa.

Górka K., Poskrobko B., Radecki W. (2001), Ochrona środowiska, Polskie Wydawnictwo Ekonomiczne, Warszawa.

Izba Gospodarcza Ciepłownictwo Polskie, Ogranicz smog w mieście, https://www.cieplosystemowe.pl/ cieplo-systemowe/miasta-bez-smogu/ogranicz-smog-w-miescie/, 6.08.2021.

Jędrzejewska Z., Jodłowski K., Knap K. et al. (2019), Ziemianie atakują!, Kantar report, Warszawa, https://ziemianieatakuja.pl, 18.07.2021.

Juda-Rezler K. (2006), Oddziaływanie zanieczyszczeń powietrza na środowisko, Oficyna Wydawnicza Politechniki Warszawskiej, Warszawa.

Kleczkowski P. (2020), Smog w Polsce. Przyczyny, skutki, przeciwdziałanie, Wydawnictwo Naukowe PWN, Warszawa.

Koalicja Obywatelska (2019), Twoja Polska. Program Koalicji Obywatelskiej, Warszawa.

Komitet Wyborczy Sojusz Lewicy Demokratycznej (Lewica) (2019), Polska jutra. Główne postulaty Lewicy, Warszawa.

Komitet Wyborczy Wyborców Mniejszość Niemiecka (2019), Opolskie ma znaczenie, https://www. mniejszoscniemiecka.eu/program/\#ekologia, 16.08.2021.

Konfederacja Wolność i Niepodległość (2019), Polska dla Ciebie, Warszawa.

Macek I. (2014), Polityka ochrony środowiska. Partie Zielonych, in: Studia nad wspótczesnymi systemami politycznymi. Podmioty i procesy demokratyczne. Księga dedykowana Profesorowi Andrzejowi Antoszewskiemu, vol. 1, eds. J. Juchnowski, R. Wiszniowski, Wydawnictwo Adam Marszałek, Torun.

Mazurek H. (2018), Konsekwencje ekspozycji dla uktadu oddechowego u dzieci, in: Smog. Konsekwencje zdrowotne zanieczyszczeń powietrza, ITEM Publishing, Warszawa.

Minister Kowalczyk o Programie Czyste Powietrze (2019), https://www.gov.pl/web/srodowisko/minister-kowalczyk-o-programie-czyste-powietrze, 28.07.2021.

Ministry of Climate and Environment (2021a), Poland's Informative Inventory Report 2021. Air Pollution Emissions in Poland 1990-2019, report elaborated by the National Centre for Emissions Management (KOBiZE), K. Bebkiewicz, Z. Chłopek, K. Chojnacka et al., Warszawa, https:// cdr.eionet.europa.eu/pl/eu/nec_revised/iir/envyei5sq/IIR_2021_Poland.pdf, 20.07.2021.

Ministry of Climate and Environment (2021b), Poland's National Inventory Report 2021. Greenhouse Gas Inventory for 1988-2019, report elaborated by the National Centre for Emissions Management (KOBiZE), A. Olecka, K. Bebkiewicz, Z. Chłopek et al., Warszawa, https://www.kobize. $\mathrm{pl} / \mathrm{pl} /$ fileCategory/id/16/krajowa-inwentaryzacja-emisji 6.08.2021.

Od dzisiaj obowiazuja zmiany w programie „CZyste Powietrze” (2021), https://czystepowietrze.gov.pl/ od-dzisiaj-obowiazuja-zmiany-w-programie-czyste-powietrze/, 27.07.2021.

Państwowa Komisja Wyborcza (2019), Wyniki wyborów 2019 do Sejmu Rzeczypospolitej Polskiej, https://sejmsenat2019.pkw.gov.pl/sejmsenat2019/pl/wyniki/sejm/pl, 18.07.2021.

Państwowa Komisja Wyborcza (2015a), Wyniki wyborów 2015 do Sejmu Rzeczypospolitej Polskiej, https://parlament2015.pkw.gov.pl/349_Wyniki_Sejm.html, 22.07.2021.

Państwowa Komisja Wyborcza (2015b), Wyniki wyborów 2015 do Senatu Rzeczypospolitej Polskiej, https://parlament2015.pkw.gov.pl/351_Wyniki_Senat.html, 22.07.2021. 
Polskie Radio 24, PiS opublikowat program wyborczy. Nosi tytut „Polski model państwa dobrobytu”, https://polskieradio24.pl/5/1222/Artykul/2368104,PiS-opublikowal-program-wyborczy-Nositytul-Polski-model-panstwa-dobrobytu, 23.07.2021.

Polskie Stronnictwo Ludowe. Koalicja Polska (2019), Łączymy Polaków, Warszawa.

Poradnik antysmogowy (2018), Samorząd Województwa Wielkopolskiego, https://www.wfosgw.poznan.pl/wp-content/uploads/2018/04/poradnik-antysmogowy.pdf, 20.07.2021.

Poskrobko B., Poskrobko T. (2012), Zarządzanie środowiskiem w Polsce, Polskie Wydawnictwo Ekonomiczne, Warszawa.

Prawo i Sprawiedliwość (2014), Zdrowie, Praca, Rodzina, Warszawa.

Prawo i Sprawiedliwość (2019), Polski model państwa dobrobytu, Warszawa.

Program priorytetowy „, Czyste Powietrze”, 2019, version valid from 29.07.2019 to 14.05.2020, Narodowy Fundusz Ochrony Środowiska i Gospodarki Wodnej, https://portal.wfosigw.pl/wymagana-dokumentacja, 27.07.2021.

Program priorytetowy „Poprawa jakości powietrza”, Narodowy Fundusz Ochrony Środowiska i Gospodarki Wodnej, http://nfosigw.gov.pl/gfx/nfosigw/userfiles/files/srodki_krajowe/programy_2018/poprawa_jakosci_powietrza/cz2/pp_3.1_poprawa_jakosci_powietrza._cz.2_zmniejszenie_zuzycia_energii_w_budownictwie.pdf, 23.07.2021.

Pytliński Ł. (2018), Stan techniczny budynków jednorodzinnych w Polsce. Potrzeby remontowe, źródła ogrzewania i standardy izolacyjności cieplnej. Raport z badań, in: Efektywność energetyczna w Polsce. Przeglad 2017. Domy jednorodzinne. Smog, eds. E. Walczak, M. Zaborowski, Instytut Ekonomii Środowiska, Kraków.

Pytliński Ł. (2014), Wegiel, stare piece i brak ocieplenia. Systemy grzewcze i izolacja termiczna w sektorze domów jednorodzinnych w Polsce. Raport z badań, in: Domy jednorodzinne: efektywność energetyczna a jakość powietrza, Instytut Ekonomii Środowiska, Kraków.

Rozporządzenie Ministra Energii z dnia 27 września 2018 r. w sprawie wymagań jakościowych dla paliw statych, Journal of Laws from 2018, item 1890.

Rozporzadzenie Ministra Przedsiębiorczości i Technologii z dnia 21 lutego 2019 r. zmieniające rozporzadzenie w sprawie wymagań dla kottów na paliwo stałe, Journal of Laws from 2019, item 363.

Rozporządzenie Ministra Rozwoju i Finansów z dnia 1 sierpnia 2017 r. w sprawie wymagań dla kottów na paliwo state, Journal of Laws from 2017, item 1690.

Rubczyński A., Czas na ciepłownictwo, Policy Paper no. 12/2019, Polski Instytut Ekonomiczny, Warszawa.

Special Eurobarometer 497, Attitudes of Europeans towards Air Quality, Kantar report on behalf of the European Commission.

Sakson-Boulet A. (2020), Ambient Air Pollution as a Human Security Challenge in Poland, "Bezpieczeństwo. Teoria i Praktyka”, no. 1 (XXXVIII).

Szatanowska A., Kotlewska K., Licznerska M. et al. (2018), Trackingowe badanie świadomości i zachowań ekologicznych mieszkańców Polski. Raport z badania, report for the Ministry of the Environment, https://www.gov.pl/web/klimat/badania-swiadomosci-ekologicznej, 18.07.2021.

Urząd Regulacji Energetyki (2019), Energetyka cieplna w liczbach 2018, Warszawa.

\section{Polityka ochrony powietrza \\ w polskiej kampanii parlamentarnej z 2019 roku. Analiza stanowisk}

\section{Streszczenie}

Cel artykułu stanowi zbadanie czy komitety wyborcze, które w wyborach parlamentarnych z 2019 r. zdobyły mandaty dostrzegły zaniepokojenie społeczeństwa problemem powietrza niespełniającego 
normatywnych standardów i zaproponowały Polakom konkretną wizję kreowania polityki ochrony powietrza w swoich programach wyborczych. Analiza koncentruje się na propozycjach komitetów wyborczych ograniczenia tzw. niskiej emisji. Odpowiedzi na postawione pytania badawcze: (1) w jakim zakresie programy wyborcze odnoszą się do kwestii zanieczyszczenia powietrza w Polsce?; (2) czy wskazano narzędzia realizacji polityki ekologicznej w aspekcie odnoszącym się do ograniczenia niskiej emisji i czy mogą one być skuteczne? prowadzą do wniosku, że zwycięskie komitety wyborcze dostrzegły zaniepokojenie społeczeństwa problemem powietrza niespełniającego normatywnych standardów, odnosząc się jednak do polityki ochrony powietrza w zróżnicowanym zakresie, a co za tym idzie, nie zawsze przedstawiając konkretne rozwiązania wyeliminowania niskiej emisji. Próbę odpowiedzi na wskazane pytania podjęto przy wykorzystaniu metody analizy źródeł oraz porównawczej.

Słowa kluczowe: polityka ochrony środowiska, bezpieczeństwo ekologiczne, polityka ochrony powietrza, programy wyborcze; partie polityczne 
